University of Nebraska - Lincoln

DigitalCommons@University of Nebraska - Lincoln

Does Presence of Permanent Fresh Water Affect Recruitment in Prairie-Nesting Dabbling Ducks?

\author{
Gary Krapu \\ USGS Northern Prairie Wildlife Research Center, gkrapu@usgs.gov \\ Pamela Pietz \\ USGS Northern Prairie Wildlife Research Center, ppietz@usgs.gov \\ David Brandt \\ USGS Northern Prairie Wildlife Research Center \\ Robert Cox Jr. \\ USGS Northern Prairie Wildlife Research Center
}

Follow this and additional works at: https://digitalcommons.unl.edu/usgsnpwrc

Part of the Other International and Area Studies Commons

Krapu, Gary; Pietz, Pamela; Brandt, David; and Cox, Robert Jr., "Does Presence of Permanent Fresh Water Affect Recruitment in Prairie-Nesting Dabbling Ducks?" (2004). USGS Northern Prairie Wildlife Research Center. 58.

https://digitalcommons.unl.edu/usgsnpwrc/58

This Article is brought to you for free and open access by the US Geological Survey at DigitalCommons@University of Nebraska - Lincoln. It has been accepted for inclusion in USGS Northern Prairie Wildlife Research Center by an authorized administrator of DigitalCommons@University of Nebraska - Lincoln. 


\title{
DOES PRESENCE OF PERMANENT FRESH WATER AFFECT RECRUITMENT IN PRAIRIE-NESTING DABBLING DUCKS?
}

GARY L. KRAPU, ${ }^{1}$ U.S. Geological Survey, Northern Prairie Wildlife Research Center, 8711 37th Street SE, Jamestown, ND 58401, USA

PAMELA J. PIETZ, U.S. Geological Survey, Northern Prairie Wildlife Research Center, 8711 37th Street SE, Jamestown, ND 58401, USA

DAVID A. BRANDT, U.S. Geological Survey, Northern Prairie Wildlife Research Center, 8711 37th Street SE, Jamestown, ND 58401, USA

ROBERT R. COX, JR., U.S. Geological Survey, Northern Prairie Wildlife Research Center, 8711 37th Street SE, Jamestown, ND 58401, USA

\begin{abstract}
In the Prairie Pothole Region (PPR) of North Dakota, USA, American mink (Mustela vison) are a major predator of ducklings. Mink populations plummet during severe droughts, but some mink survive where permanent fresh water is available. In 1992-1993, we evaluated whether development of a permanent water body, the 125km McClusky Canal (MC), had affected survival of gadwall (Anas strepera) and mallard (A. platyrhynchos) broods and ducklings in surrounding wetland complexes. Twelve of 25 radiomarked gadwall and mallard hens experienced total brood loss, and 148 of 199 radiomarked ducklings from 58 broods died by day 30 . Gadwall broods ( $n$ $=18$ radiomarked hens) survived to 30 days at a lower rate $(0.52)$ than predicted for similar areas in the region with limited permanent fresh water $(0.85 ; P=0.009)$. Observed $(n=162$ radiomarked ducklings from 48 broods $)$ survival rates also were lower than predicted for gadwall ducklings $0-7$ days old $(0.42$ vs. $0.60 ; P<0.001)$ and $8-30$ days old $(0.41$ vs. $0.80 ; P<0.001)$. We attempted to include mallards in models constructed to predict brood and duckling survival rates in the Koenig Study Area (KSA), but data were too sparse. Rates of survival to 30 days for gadwall and mallard ducklings declined from an estimated 0.83 and 0.68 in 1976-1981 (Lokemoen et al. 1990), when the MC was first filling with water, to 0.36 and 0.31 (adjusted for radiotransmitter effects) in 1992-1993 after the MC had become a permanent freshwater body. Estimated gadwall recruitment rate (females fledged per hen) during 1992-1993 was $0.5,<50 \%$ of the estimated recruitment rate in 1976-1981. Of 130 radiomarked ducklings (both species) for which we determined cause of death, 114 mortalities were attributed to predation; at least $65 \%$ of 62 deaths in which the predator type could be discerned were caused by mink. Environmental planners and waterfowl managers should be aware of potential risks to waterfowl production from development of permanent freshwater bodies in prairie pothole landscapes and may wish to refine duck productivity models to consider negative effects of permanent water on duckling survival.
\end{abstract}

JOURNAL OF WILDLIFE MANAGEMENT 68(2):332-341

Key words: Anas platyrhynchos, Anas strepera, brood survival, duckling survival, gadwall, mallard, mink, North Dakota, permanent wetlands, Prairie Pothole Region, recruitment.

The American mink (hereafter mink) is an exceptionally effective predator of ducklings and other neonatal waterbirds (Sargeant et al. 1973, Eberhardt and Sargeant 1977, Talent et al. 1983). The center of the geographic range of mink in North America is located in the Prairie Pothole Region of the north-central United States and adjacent parts of south-central Canada (Hall 1981). Although mink occur throughout the PPR, mink densities vary widely among locations and years (Bailey 1926; Soper 1946, 1961; Sargeant et al. 1993) because of their reliance on freshwater aquatic habitats (Eagle 1989). As a result, frequent widespread and local droughts that are characteristic of the PPR cause major fluctuations of mink populations (Sargeant et al. 1993). During periods

${ }^{1}$ E-mail: gary_krapu@usgs.gov of severe drought, mink are confined to freshwater lakes, rivers, deep marshes, and other permanent water areas where fish (Arnold 1986), muskrats (Ondatra zibethicus; Errington 1963), and other preferred foods remain available. Because permanent freshwater wetlands historically have been relatively scarce across much of the PPR, widespread droughts that occurred during the 1910s, 1930s, late 1950s to early 1960s (Stoudt 1971, Kiel et al. 1972) and 1988-1992 (Winter and Rosenberry 1998) probably had catastrophic effects on mink abundance (Sargeant et al. 1993).

In recent decades, permanent water bodies have been created in the PPR to increase cropland through wetland consolidation, and to provide for water-based recreation, flood control, irrigation, sewage treatment, livestock watering, and waterfowl habitat. As a result, mink populations likely are becoming less affected by prairie 
droughts than in the past. In landscapes where permanent fresh water has increased, mink presumably require less time to reoccupy surrounding natural wetland complexes when wet conditions return, potentially reducing productivity of waterbirds that breed in the PPR. However, we lack information on the influence of human-created and naturally occurring permanent freshwater bodies in prairie pothole landscapes on waterbird recruitment and mink population dynamics. Given the increased potential for mink predation, we hypothesized that prefledged waterfowl would experience lower survival rates and fewer young would be recruited into fall populations at sites with extensive permanent fresh water than at sites with limited permanent fresh water.

The most recent major drought in the PPR during 1988-1992 was followed by an extremely wet period (Winter and Rosenberry 1998, Krapu et al. 2001), providing conditions well suited to evaluating our hypothesis. We selected the Koenig Study Area in central North Dakota to assess effects of the presence of permanent freshwater habitat on duckling survival. The KSA is bisected by the McClusky Canal, which was built by the U.S. Bureau of Reclamation in the late 1960s and 1970s as part of the Garrison Diversion Unit (U.S. Bureau of Reclamation 1974). The section of the MC located on the KSA was filled with water in 1979 (M. Marohil, U.S. Bureau of Reclamation, personal communication).

We chose the KSA for our study in part because estimates of gadwall and mallard duckling survival were available from 1976 to 1981 (Lokemoen et al. 1990), allowing gadwall and mallard duckling survival to be compared before and after the MC developed into a permanent freshwater body. The MC extends for $125 \mathrm{~km}$, mostly through prairie pothole landscapes (U.S. Bureau of Reclamation 1974), and is within $3.6 \mathrm{~km}$ of $>11,000$ wetland basins (G. Krapu, unpublished data). Shallow basins are plentiful near the MC throughout much of its length, attracting large numbers of breeding waterfowl in years when ponds (i.e., basins holding water) are abundant. As a result, the potential exists for a major reduction in waterfowl production in this area of central North Dakota if survival rates of young ducks have been negatively affected by the MC. Studying survival rates of ducklings in wetland complexes near the MC also afforded us an opportunity to predict the impact of the MC outside the KSA. Specifically, we (1) estimated survival rates of gadwall broods and ducklings inhabiting prairie wetland complexes surrounding the MC in 1992-1993 and compared these rates to those predicted from models developed for control areas (Pietz et al. 2003); (2) compared survival rates of gadwall and mallard ducklings reared in wetland complexes surrounding the MC in 1976-1981, before the MC became a permanent water body, with survival rates in 1992-1993; (3) predicted recruitment rates of gadwalls from landscapes surrounding the MC under varying levels of hen success and duckling survival, and compared these to estimated recruitment rates before the $\mathrm{MC}$ was built; and (4) identified proximate causes of death for gadwall and mallard ducklings in wetland complexes near the MC during 1992-1993.

\section{STUDY AREAS}

Koenig Study Area.-The KSA $\left(47^{\circ} 23^{\prime} \mathrm{N}\right.$, $100^{\circ} 49^{\prime} \mathrm{W}$ ) was located in the Missouri Coteau in McClean County, North Dakota, 13 km southwest of Mercer. It was about $40 \mathrm{~km}^{2}$, with an estimated $41 \%$ of the area in cropland and $40 \%$ in native and planted upland cover (Fig. 1). Most of the remaining area was occupied by 700 wetland basins with temporarily flooded (19 ha), seasonally flooded (350 ha), semipermanently flooded (281 ha), and intermittently exposed (191 ha) water regimes. Wetland habitat with an intermittently exposed water regime goes dry during periods of extreme drought and has a mixosaline water chemistry that limits plant growth (Cowardin et al. 1979). The part of the MC that was located within the KSA contained 35.7 ha of permanent freshwater habitat. About 25\% of the study area was in public ownership and managed by the U.S. Fish and Wildlife Service as the Koenig Wildlife Development Area (WDA). The remainder of the study area was privately owned and mostly in livestock and/or small-grain farming operations.

The MC is part of a planned system of canals and reservoirs designed to transport and store water for irrigation and municipal and industrial use in eastern North Dakota. It extends from Lake Audubon, an impounded arm of Lake Sakakawea (a mainstem reservoir on the Missouri River), to the headwaters area of the Sheyenne River and James River. Construction of the MC was halted when nearly completed due to national and international environmental concerns (Garrison Diversion Unit Commission 1984). An earthen plug was retained in the last reach of the MC to prevent mixing of waters from Lake Audubon (Missouri River Basin) with those of 


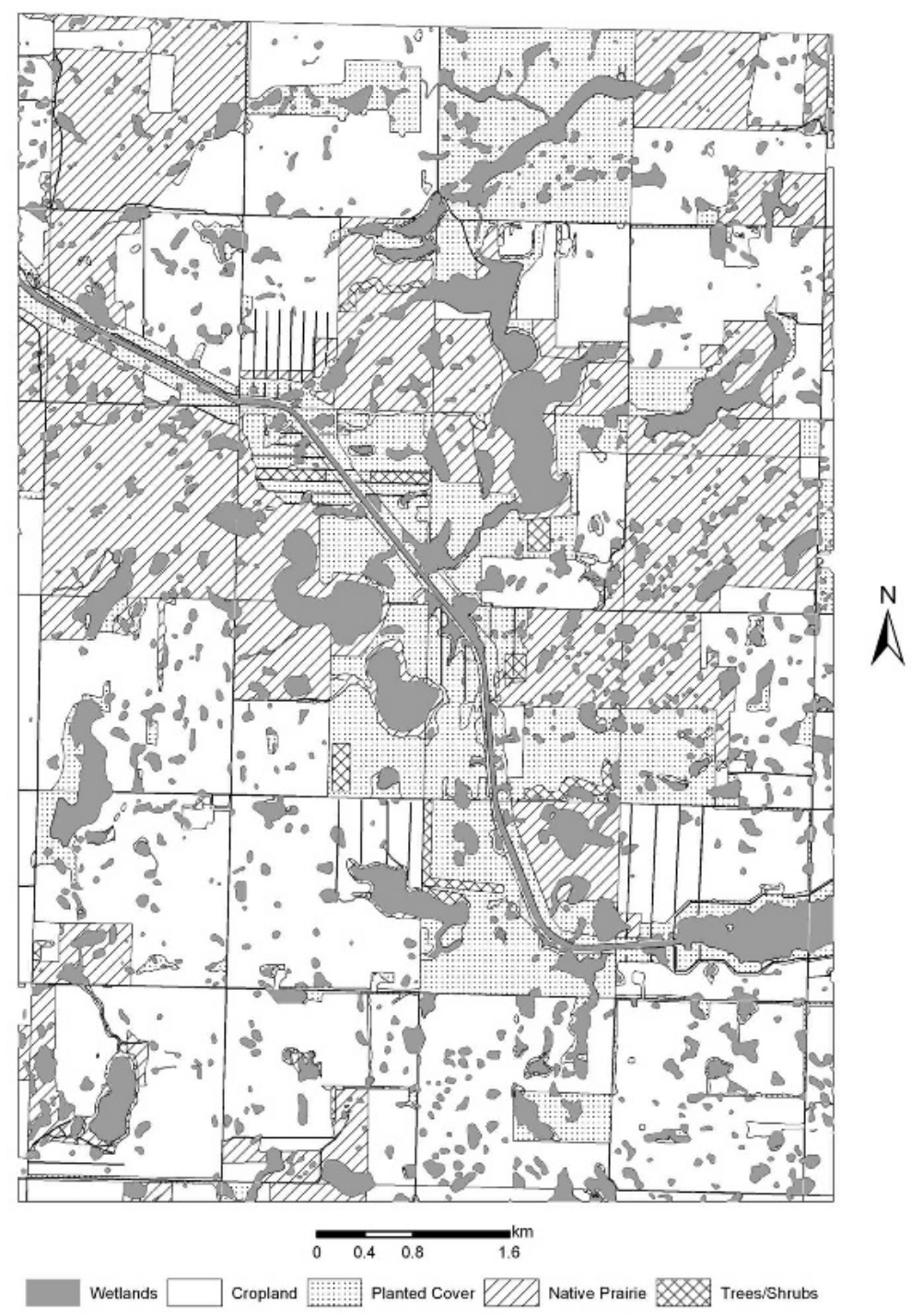

Fig. 1. Koenig Study Area in central North Dakota, USA, where survival of radiomarked gadwall and mallard brood hens and their ducklings was monitored during 1992-1993. The McClusky Canal crosses the study area diagonally from northwest (upper left) to southeast. Vertical and horizontal lines on the landscape identify single rows of trees planted in cropland to reduce soil erosion.

the Sheyenne River (Red River Basin) across the Continental Divide. Water depth in the MC was maintained at about $5.3 \mathrm{~m}$ through pumping to minimize slumping of the unlined earthen canal walls (U.S. Department of the Interior 1979). Most of the KSA lies within $3.6 \mathrm{~km}$ of the MC (Fig. 1).

Control Study Areas.-Parameters that we used to predict gadwall brood and duckling survival on the KSA came from statistical models (proportional hazards regression) developed from re- search conducted during 1990-1994 on 2 51$\mathrm{km}^{2}$ study areas (Pietz et al. 2003). These study areas were located in the Missouri Coteau and glaciated drift plain of eastern North Dakota and were typical of the PPR with respect to abundance of permanent water. One control study area was located 14 $\mathrm{km}$ south of Kulm in Dickey County and contained 17 ha of intermittently exposed wetland but lacked permanent freshwater wetlands. The other control area was $27 \mathrm{~km}$ north of Jamestown in Stutsman County and had 1 ha of permanent wetland habitat. Vegetative cover and wetland habitat types on the Kulm and Jamestown study areas were described previously (Krapu et al. 2000: study areas 1 and 4).

\section{METHODS}

\section{Field Procedures}

In 1992-1993, we located gadwall and mallard nests by systematically searching fields of perennial upland vegetation. Nest searching was conducted by dragging a chain between 2 vehicles to flush hens from nests (Klett et al. 1986). When a nest was located, we candled the eggs to determine developmental stage (Weller 1956). Beginning about 15 days after the onset of incubation, we used modified bow traps (Salyer 1962) or walk-in traps (Dietz et al. 1994) to capture nesting hens. We fitted each hen with a 4-g anchor radiotransmitter (Pietz et al. 1995) and a unique combination of nasal markers (Lokemoen and Sharp 1985). To reduce the risk of nest abandonment, we then anes- 
thetized the hen with methoxyflurane (Rotella and Ratti 1990) and placed her next to the nest. At nests where gadwall and mallard hens were radiomarked and also at nests of nonradiomarked hens, we web-tagged ducklings at hatch and attached radiotransmitters to 1-4 randomly selected ducklings per brood. Duckling radiotransmitters weighed $1.5-1.8 \mathrm{~g}$ and were attached with sutures and a subcutaneous anchoring device (1992-1994) modified from Mauser and Jarvis (1991).

From radiotracking trucks, we obtained maximum ranges of $2-3 \mathrm{~km}$ and $1.5 \mathrm{~km}$ for hen and duckling radiotransmitters, respectively. We attempted to monitor each brood with a radiomarked hen or radiomarked duckling(s) continuously from the time the brood left the nest until it reached a wetland. Thereafter, we attempted to locate all radiomarked birds daily, and we attempted to visually check each radiomarked brood to detect losses of nonradiomarked ducklings. If we could not visually locate a radiomarked bird, we recorded the bird's location and radio status using standard telemetry methods (Mech 1983). We aerially searched (Gilmer et al. 1981) for missing radiomarked birds weekly.

Radiotransmitters were equipped with mortality sensors (mercury switches or thermistors), and we attempted to retrieve carcasses as soon as possible when sensors indicated that a death had occurred. We thoroughly examined sites where remains were located for clues related to cause of death. These clues included location of remains (e.g., at a den or raptor nest, cached, hidden under vegetation, at the base of a perch); presence and type of tracks, scats, or egested pellets; and condition of surrounding vegetation. Type and condition of remains were noted, and if the carcass was sufficiently fresh and complete, a necropsy was performed by an avian pathologist. Evidence of mink predation included appropriately spaced tooth marks in remains, associated tracks and scats, and location of remains (e.g., mink dens or over-water sites that excluded other predators).

\section{Brood Survival Analysis}

A brood was defined as surviving if $\geq 1$ duckling survived to $\geq 30$ days old. Pietz et al. (2003) presented detailed descriptions of methods used to analyze data and construct models on gadwall brood survival at control sites. In our predictive model, survival of gadwall broods was affected only by brood size adjusted for the influence of hatch date (see Pietz et al. 2003). We calculated the mean value of this predictor from our sample of gadwall brood exposure days on the KSA and used this value in a proportional hazards regression model to predict Kaplan-Meier survival for gadwall broods. We compared this predicted brood survival to that actually observed on the KSA using generalized chi-square procedures (Sauer and Williams 1989). We attempted to make similar comparisons of predicted and observed survival rates for mallard broods and ducklings, but mallard data from the KSA were too sparse for this analysis.

\section{Duckling Survival Analysis}

Parameters taken into account when estimating survival of gadwall ducklings on the KSA were those found to influence duckling survival on control sites. A detailed description of methods used to analyze data and construct models on gadwall duckling survival is given by Pietz et al. (2003). Environmental variables used in our predictive gadwall duckling model were WETSEAS, RAIN $\times$ AGE, and RAIN $\times$ TEMP. We defined WETSEAS as the percent of seasonal basins containing water. The value for RAIN (time dependent, binary) was " 1 " if rain had fallen (including values recorded as trace) on the current or 2 previous days and " 0 " otherwise. We defined TEMP (time-dependent, binary) as the average of daily minimum temperatures from the current and 2 previous days, categorized as $\leq 10^{\circ} \mathrm{C}$ or $>10^{\circ} \mathrm{C}$.

Survival of gadwall ducklings did not seem to be proportional throughout the range of temperatures that gadwall ducklings were exposed to (i.e., a temperature threshold appeared to be present). Therefore, we categorized TEMP with a threshold of $10^{\circ} \mathrm{C}$ (Koskomies and Lahti 1964) to avoid violating a key assumption of proportional hazards regression. We obtained precipitation and minimum temperature measurements from the nearest National Weather Service observation station located $16 \mathrm{~km}$ northeast of the KSA (National Oceanic and Atmospheric Administration 1992-1993). We categorized brood AGE (time-dependent, binary) as 0-7 or 8-30 days old because ducklings generally exhibit lower survival rates during 0-7 days (Gendron and Clark 2002). Lower survival during the first week presumably is associated in part with increased risk since ducklings deplete endogenous nutrients during the first 3 days (Marcstrom 1966) and must rapidly become adept at foraging while learning to avoid predators. We limited estimation of survival rates to $0-30$ days as most brood 
Table 1. Average environmental conditions experienced by radiomarked gadwall and mallard ducklings in 1992 and 1993 on the Koenig Study Area in North Dakota, USA.

\begin{tabular}{|c|c|c|c|c|}
\hline Species/year & $n^{\mathrm{a}}$ & $\begin{array}{l}\% \text { seasonal } \\
\text { basins } \text { wet }^{\mathrm{b}}\end{array}$ & $\begin{array}{l}\text { Minimum } \\
\quad \text { daily } \\
\text { temp }\left({ }^{\circ} \mathrm{C}\right)^{\mathrm{c}}\end{array}$ & $\begin{array}{l}\% \text { exposure } \\
\text { days with } \\
\text { RAIN }^{\text {d }}\end{array}$ \\
\hline \multicolumn{5}{|l|}{ Gadwall } \\
\hline 1992 & 529 & 17.8 & 9.7 & 78.3 \\
\hline 1993 & 811 & 46.0 & 10.2 & 77.9 \\
\hline \multicolumn{5}{|l|}{ Mallard } \\
\hline 1992 & 166 & 22.1 & 9.0 & 67.9 \\
\hline 1993 & 90 & 48.8 & 8.4 & 86.7 \\
\hline \multicolumn{5}{|c|}{$\begin{array}{l}\text { a Number of duckling exposure days. } \\
\text { b Percent of seasonal wetland basins containing water, aver- } \\
\text { aed across duckling exposure days. } \\
\text { c Mean minimum daily temperature on current and previous }\end{array}$} \\
\hline
\end{tabular}

and duckling mortality occurs by day 30 (Ball et al. 1975, Talent et al. 1983, Orthmeyer and Ball 1990).

We compared predicted survival rates (KaplanMeier) of gadwall ducklings to the survival rates actually observed on the KSA using a randomization test (Manly 1991). We generated a distribution of gadwall duckling survival rates on the KSA. Each survival rate in the distribution was calculated using the actual fate of 1 randomly selected duckling from each brood. We repeated this process, with replacement, 10,000 times. We estimated an empirical 1-tailed $P$-value for the null hypothesis that the actual survival rate was lower than the predicted survival rate by examining the rank of the predicted survival rate within the upper end of the generated distribution. We also calculated empirically derived $95 \%$ confidence intervals for actual survival rates as above, and naive (i.e., not accounting for intrabrood correlation) confidence intervals for predicted survival rates. We present naive confidence intervals for predicted survival rates because we are not aware of any technique that allows one to account for intrabrood correlation when predicting survival rates from a proportional hazards regression model.

To compare estimated survival rates of our radiomarked gadwall and mallard ducklings with those reported by Lokemoen et al. (1990) for nonradiomarked ducklings, we adjusted our survival rates to account for effects of radiotransmitters (Pietz et al. 2003; G. Krapu, unpublished data). For this comparison, we added 0.19 and 0.16 to our 30-day survival rates for gadwall and mallard ducklings, respectively. Lokemoen et al. (1990) reported sur- vival of gadwall ducklings to 34 days and mallard ducklings to 45 days and thus provided a conservative comparison for our 30-day survival rates.

To help waterfowl managers relate our duckling survival rates to subsequent gadwall recruitment rates under varying levels of hen success, we estimated recruitment rates (number of female ducks fledged per breeding female in the spring population) for gadwalls as

\section{(hen success rate $\times$ duckling survival rate $\times$ mean clutch size at hatching) $/ 2$.}

We assumed ducklings that lived to be $\geq 30$ days old fledged. Mean clutch size at hatching was 8.44, the average number of eggs in completed gadwall clutches on the KSA in 1992. We obtained gadwall hen success rates from data collected over a 17-year period at the Woodworth Field Station in the Missouri Coteau in central North Dakota (Higgins et al. 1992). Average hen success across the 17 years was $30 \%$ (range $=8-73 \%$ ).

\section{RESULTS}

In 1992, the proportion of seasonal basins containing water was relatively low on both the KSA (Table 1) and control areas (Pietz et al. 2003). In 1993, the proportion of wet seasonal basins increased substantially on all study areas. In 1992 and 1993, gadwall and mallard broods occupied wetland complexes surrounding the MC; brood use of the MC was limited to an occasional crossing when traveling between natural wetlands.

During 1992-1993, 12 of 25 radiomarked gadwall and mallard hens experienced total brood loss, and 148 of 199 radiomarked ducklings from 58 broods died by day 30 (Table 2). For gadwalls, the observed 30-day survival rate of broods on the

Table 2. Numbers of radiomarked gadwall and mallard broods and ducklings monitored and losses on the Koenig Study Area, North Dakota, USA, 1992-1993.

\begin{tabular}{|c|c|c|c|c|c|c|}
\hline & \multicolumn{3}{|c|}{ Gadwall } & \multicolumn{3}{|c|}{ Mallard } \\
\hline & 1992 & 1993 & Total & 1992 & 1993 & Total \\
\hline $\begin{array}{l}\text { Broods with radio- } \\
\text { marked hens }\end{array}$ & 5 & 13 & 18 & 5 & 2 & 7 \\
\hline Total brood losses & 3 & 5 & 8 & 3 & 1 & 4 \\
\hline $\begin{array}{l}\text { Radiomarked } \\
\text { ducklings } \\
\text { Radiomarked } \\
\text { duckling } \\
\text { deaths }\end{array}$ & 74 & 88 & $162^{\mathrm{a}}$ & 25 & 12 & $37^{b}$ \\
\hline
\end{tabular}

a From 48 broods.

b From 10 broods. 
Table 3. Observed and predicted Kaplan-Meier survival rates of gadwall ducklings on the Koenig Study Area, North Dakota, USA, 1992-1993.

\begin{tabular}{cccc}
\hline Year & $\begin{array}{c}\text { Brood } \\
\text { age (days) }\end{array}$ & $\begin{array}{c}\text { Observed } \\
\text { survival }\end{array}$ & $\begin{array}{c}\text { Predicted } \\
\text { survival }\end{array}$ \\
\hline 1992 & $0-7$ & 0.372 & 0.461 \\
& $8-30$ & 0.375 & 0.704 \\
1993 & $0-30$ & 0.140 & 0.325 \\
& $0-7$ & 0.473 & 0.694 \\
& $8-30$ & 0.436 & 0.839 \\
& $0-30$ & 0.206 & 0.582 \\
\hline
\end{tabular}

KSA (258 exposure days) was lower than that predicted from our model $(0.52 \pm 0.12$ [SE] vs. 0.85 $\left.\pm 0.05 ; \chi^{2}=6.89, \mathrm{df}=1, P=0.009\right)$. Observed survival rates on the KSA were lower than predicted rates for radiomarked gadwall ducklings $(1,340$ exposure days) $0-7$ days old $(0.42[95 \% \mathrm{CI}=0.31$ to 0.53 ] vs. 0.60 [naive $95 \% \mathrm{CI}=0.52$ to 0.68 ]; $P<$ $0.001)$ and $8-30$ days old $(0.41[95 \% \mathrm{CI}=0.27$ to 0.57 ] vs. 0.80 [naive $95 \% \mathrm{CI}=0.70$ to 0.90 ]; $P<$ 0.001 ; Table 3).

On the KSA, gadwall and mallard duckling survival rates were estimated to be 0.83 and 0.68 , respectively, during 1976-1981 (Lokemoen et al. 1990) and 0.36 and 0.31 in 1992-1993 (after adjusting for radiotransmitter effect). Using an average gadwall hen success of $30 \%$, we estimated gadwall recruitment rate on the KSA to be 0.46 females fledged per hen during 1992-1993. From our model, we predicted that 0.84 gadwall females should have fledged per hen under

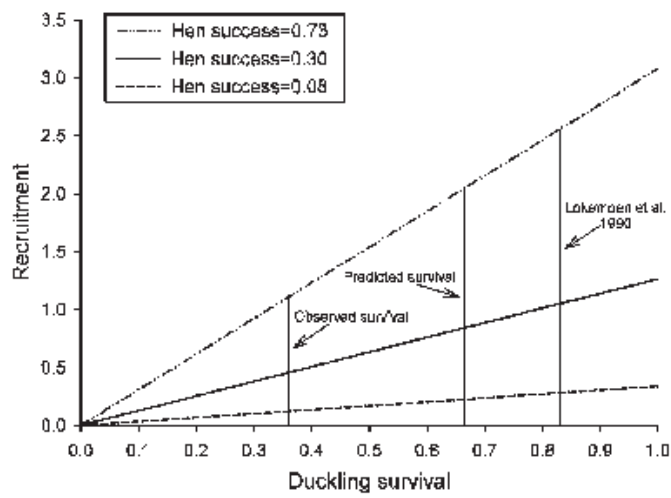

Fig. 2. Estimated gadwall recruitment in wetland complexes near the McClusky Canal in North Dakota, USA, in relation to observed and predicted duckling survival in 1992-1993 (our study), and prior to the McClusky Canal becoming a permanent freshwater body (1976-1981; Lokemoen et al. 1990). Hen success rates of $0.73,0.30$, and 0.08 represent the maximum, average, and minimum annual hen success rates recorded over a 17-year period at the Woodworth Field Station in central North Dakota (Higgins et al. 1992).
Table 4. Assigned causes of death for radiomarked gadwall and mallard ducklings monitored on the Koenig Study Area, North Dakota, USA, 1992-1993.

\begin{tabular}{lrrrrr}
\hline \multirow{2}{*}{ Cause of death } & \multicolumn{2}{c}{ Gadwall } & & \multicolumn{2}{c}{ Mallard } \\
\cline { 2 - 3 } \cline { 5 - 6 } & \multicolumn{1}{c}{$n$} & $\%$ & & $\%$ \\
\hline Predation & 95 & 88 & & 19 & 86 \\
Mammalian & 35 & 32 & & 10 & 45 \\
$\quad$ American mink & 30 & 28 & & 10 & 45 \\
$\quad$ Red fox & 4 & 4 & & \\
$\quad$ Raccoon & 1 & 1 & & \\
Avian & 14 & 13 & 2 & 9 \\
$\quad$ Great horned owl & 2 & 2 & & \\
$\quad$ Unidentified avian predator & 12 & 11 & 2 & 9 \\
Fish & 1 & 1 & & \\
$\quad$ Unidentified predator & 45 & 42 & 7 & 32 \\
Exposure & 13 & 12 & 3 & 14 \\
Totals & 108 & 100 & 22 & 100 \\
\hline
\end{tabular}

1992-1993 conditions on the KSA (Fig. 2). Using Lokemoen's duckling survival rate estimated before the MC had become a permanent freshwater body, we would expect 1.05 females fledged per hen using the same hen success rate and average clutch size as above.

During 1992-1993, we assigned proximate cause of death for 130 radiomarked ducklings (Table 4). Eighty-eight percent of gadwall and $86 \%$ of mallard duckling deaths were attributed to predation. Exposure was the second major cause of death for both species (gadwall: 12\%, mallard: $14 \%)$. We were able to assign the type of predator responsible for 62 predation deaths of which $65 \%$ were attributed to mink and $26 \%$ to avian predators.

\section{DISCUSSION}

Observed survival of gadwall broods and ducklings on the KSA was lower than predicted, which supports the hypothesis that duck production in the PPR is lower in wetland complexes near a permanent freshwater body. If duckling survival rates documented near the MC are representative of those near other sources of permanent fresh water in the PPR, gadwall recruitment in the PPR has been reduced by the proliferation of permanent freshwater bodies over the past century.

Our hypothesis that the building of the MC reduced duckling survival in surrounding wetland complexes was supported by the marked decline in both gadwall and mallard duckling survival from 1976-1981 (Lokemoen et al. 1990) to 1992-1993. Lokemoen et al. (1990) estimated duckling survival by using a combination of recapture rates of web-tagged ducklings in the year after tagging and resighting rates of nasal- 
marked fledglings in the year after marking. Lokemoen et al.'s (1990) survival estimates were pooled over several years and thus may have ignored several sources of heterogeneity. Further, loss of nasal markers between years would have biased their survival rates high. However, loss of web tags or increased likelihood of resightings of nasal markers compared to recaptures of webtagged individuals in subsequent years would have biased their survival estimates low. Lokemoen et al. (1990) calculated a nasal marker loss rate of 0.04 for females passing through their first winter, and Blums et al. (1997) calculated a web-tag loss rate for mallards of 0.045 . This suggests webtag loss rates were similar to, if not greater than, nasal-marker loss rates. Moreover, Lokemoen et al. (1990) concluded, "Our estimate of [duckling] survival was probably minimal [conservative] because it was derived by comparing return rates of web-tagged hens (which had to be recaptured to be identified) with those of nasal-marked hens." We could not present statistical comparisons between duckling survival estimates from the 2 periods because of difficulties in calculating variances on survival estimates presented in Lokemoen et al. (1990) and on those adjusted for radiotransmitter effects in our study. However, the magnitude of difference ( $>50 \%$ decline for both species) provides compelling evidence that duckling survival rates were lower in 1992-1993.

We conducted our study during the last year of a severe multi-year drought and during the first year of the subsequent wet period; thus few mink would have been expected to occur on the KSA had extensive permanent freshwater habitat not been present. Conversely, the 1976-1981 study was conducted over a wide range of water conditions that started wet and ended relatively dry, presumably concentrating mink. The fact that duckling survival was high on the KSA during 1976-1981—over a period of widely varying water conditions-further supports our hypothesis that presence of extensive permanent freshwater habitat on the KSA by 1992-1993 adversely affected brood and duckling survival.

Several sources of information support the conclusion that mink predation was the principal cause of low recruitment on the KSA in 1992-1993. We frequently sighted mink and their sign (i.e., tracks and scats), indicating that mink were abundant throughout our study area despite the regional drought. Necropsies of ducklings and sign at sites where remains of radiomarked ducklings and/or radiotransmitters were found implicated mink as the primary predator of ducklings of both species (Table 4). Most remains attributed to "unidentified predator" were found in or near wetlands and no other wetland predator approached mink in terms of numbers, distribution, or effectiveness as a hunter of wetland-based avian prey, suggesting that mink were responsible for a major part of unidentified predator losses. The relatively low survival of ducklings from 8 to 30 days on the KSA (Table 3) further implicates the role of mink predation. In PPR landscapes unaltered by creation of permanent water bodies, survival rates generally are much higher for older age groups of ducklings than for younger groups (Talent et al. 1983, Gendron and Clark 2002, Pietz et al. 2003). However, this was not true for older ducklings on the KSA (Table 3). Mink are a major predator of both older ducklings and adult ducks (Eberhardt 1973).

Individually, most permanent freshwater bodies are much smaller than the MC, support fewer mink, and can be expected to have much less effect on waterfowl production. However, the many human-created or human-altered water bodies in the PPR that now rarely go dry may have a large cumulative effect on waterfowl recruitment. At individual rearing dens of mink in the Missouri Coteau in North Dakota, remains of up to 103 American coots (Fulica americana) and 27 ducks were found in a single nesting season (Eberhardt and Sargeant 1977). Such losses, combined with the potential for rapid mink population growth when wet conditions return (mink litter size in North Dakota $=5.5$ young [Eagle 1989]) underscore the potential effect of even a few mink surviving through drought periods in landscapes where none survived previously.

With most land in the PPR in cropland and producers seeking to maximize agricultural production, wetland consolidation potentially poses the greatest long-term source of expansion of permanent fresh water. Producers often seek to drain temporary, seasonal, and semi-permanent wetlands into basins at lower elevations, thus increasing their permanency. This change not only decreases availability of food-rich habitats for nesting hens and broods (Krapu and Reinecke 1992, Murkin and Ross 2000) but also creates conditions that may allow mink to survive droughts at higher densities than in the past, thereby increasing duckling mortality from predation. Greater permanency of ponds also reduces macrophyte growth due to infrequent drawdowns and thus lowers production of macro- 
invertebrates (Murkin and Ross 2000). This in turn results in slower growth and higher mortality of ducklings (Cox et al. 1998). At the same time, wetland drainage reduces the number of seasonal ponds available, exposing duck broods to an increased risk of mortality (Krapu et al. 2000, Pietz et al. 2003).

Documented losses of gadwall and mallard ducklings on the KSA during our study undoubtedly represented a small part of the overall loss of waterbirds to mink given species diversity in remains at mink dens in the PPR (Eberhardt and Sargeant 1977, Arnold and Fritzell 1987). Relatively sedentary species such as ruddy ducks (Oxyura jamaicensis), American coots, and pied-billed grebes (Podilymbus podiceps) usually stay on 1 wetland and are likely more vulnerable to mink predation than young dabbling ducks (Eberhardt 1974). Further studies are needed to identify survival and recruitment rates of young waterbirds reared within home ranges of mink. Data on mink dispersal patterns and population dynamics during post-drought periods also are lacking. The amount of time required by mink to reoccupy landscapes following drought can be expected to vary depending on severity of the most recent drought and distance to the nearest mink refugium.

\section{MANAGEMENT IMPLICATIONS}

In typical PPR landscapes, survival of older mallard and gadwall ducklings is high when seasonal water is abundant, and most ducklings are likely to fledge (Krapu et al. 2000, Pietz et al. 2003). However, our results from the KSA indicate that gadwall duckling survival, particularly of older ducklings, remained low in the post-drought period despite the availability of productive wetland complexes with numerous shallow ponds (Fig. 1). The disparity between predicted and observed gadwall brood and duckling survival rates on the $\mathrm{KSA}$, and the sharp decline in gadwall and mallard duckling survival from 1976-1981 to 1992-1993, probably resulted in part because an abundance of permanent freshwater habitat provided by the MC created a refugium for mink during the 1988-1992 drought. As a result, duck productivity models developed for PPR landscapes may be improved by considering the effect of permanent freshwater bodies on duckling survival.

The increase in amount of permanently flooded freshwater habitat resulting from construction of the MC may have reduced duck production over a large, but as yet poorly defined, area in central North Dakota. Juvenile and adult female mink tagged in the PPR of North Dakota were relocated up to $30 \mathrm{~km}$ (Eagle 1989) and $40 \mathrm{~km}$ (A. W. Adams, North Dakota Game and Fish Department, unpublished report), respectively, from the initial marking site. This indicated that mink disperse long distances and thus can affect waterbird survival over a wide area surrounding a permanent freshwater body. Additional research is needed to gain a better understanding of the scale of influence of the MC on waterbird populations and effects of permanent freshwater bodies in general on waterbird productivity, so that effective strategies can be implemented to reduce or compensate for losses. Negative effects to waterfowl and other waterbird populations from adding permanent water to prairie pothole landscapes generally have not been addressed in environmental reviews mandated by the National Environmental Policy Act (NEPA) for federally funded projects in the United States. Our results suggest that environmental planners should consider risks to migratory waterbird populations when programs or projects are being planned that create permanent water bodies on landscapes in the PPR.

Waterfowl managers in the PPR often have supported creation of permanent freshwater habitat to provide breeding sites for waterfowl during drought periods. However, as permanent water areas also can serve as mink refugia during drought, managers should be aware that by creating permanent wetland habitat, they may increase the risk of mink predation during and after drought, potentially leading to severe reductions in duck production.

\section{ACKNOWLEDGMENTS}

Several organizations and numerous individuals provided assistance during this study. We are grateful to staff at the Audubon Wetland Management District of the U.S. Fish and Wildlife Service-and particularly C. Hultberg and J. Lang-for allowing use of their facilities and other assistance, and to the U.S. Bureau of Reclamation for providing digitized cover maps of the study area. We also appreciate the cooperation of landowners and operators for allowing access to their properties to capture and monitor broods. We are particularly grateful to B. L. Hellyer, M. R. Hill, G. G. Mack, W. A. Meeks, A. D. Olson, T. D. Thorn, and R. F. Sachs for monitoring radiomarked birds on the KSA, and D. W. Howerter, D. G. McAuley, K. D. Richkus, S. E. Sheaffer, M. A. Sovada, and an anonymous reviewer for providing helpful comments on earlier drafts of the 
manuscript. G. L. Pearson, DVM, advised on radiotransmitter attachment procedures and autopsied radiomarked ducklings. All capture and radiomarking procedures were approved by the Northern Prairie Wildlife Research Center Animal Care and Use Committee and conformed to recommendations of the American Ornithologists' Union (1988).

\section{LITERATURE CITED}

American Ornithologists' Union. 1988. Report of committee on use of wild birds in research. Auk 105 (1, Supplement).

ARNOLD, T. W. 1986. The ecology of prairie mink during the waterfowl breeding season. Thesis, University of Missouri, Columbia, Missouri, USA.

— , AND E. K. FRITZELL. 1987. Food habits of prairie mink during the waterfowl breeding season. Canadian Journal of Zoology 65:2322-2324.

BaILEY, V. 1926. A biological survey of North Dakota: I. Physiography and life zones. II. The mammals. North American Fauna 49.

Ball, I. J., D. S. Gilmer, L. M. Cowardin, and J. H. RIECHMANN. 1975. Survival of wood ducks and mallard broods in north-central Minnesota. Journal of Wildlife Management 39:776-780.

Blums, P., A. Mednis, I. Bauga, J. D. Nichols, and J. E. Hines. 1997. The loss rates of web tags applied to dayold Anas and Aythya ducklings. Wildfowl 47:181-185.

Cowardin, L. M., V. Carter, F. C. Golet, and E. T. La RoE. 1979. Classification of wetlands and deep water habitats of the United States. U.S. Fish and Wildlife Service Biological Services Program FWS/OBS-79/31.

Cox, R. R., JR., M. A. Hanson, C. C. Roy, N. H. Euliss, JR., D. H. Johnson, AND M. G. ButLer. 1998. Mallard duckling growth and survival in relation to aquatic invertebrates. Journal of Wildlife Management 62:124-133.

Dietz, N. J., P. J. Bergmann, and L. D. Flake. 1994. A walk-in trap for nesting ducks. Wildlife Society Bulletin 22:19-22.

EAGLE, T. C. 1989. Movement patterns of mink in the Prairie Pothole Region of North Dakota. Dissertation, University of Minnesota, Minneapolis, Minnesota, USA.

EBERHARDT, L. E. 1973. Some aspects of mink-waterfowl relationships on prairie wetlands. Prairie Naturalist 5:17-19.

. 1974. Food habits of prairie mink (Mustela vison) during the waterfowl breeding season. Thesis, University of Minnesota, Minneapolis, Minnesota, USA.

$\longrightarrow$, AND A. B. SARGEANT. 1977. Mink predation on prairie marshes during the waterfowl breeding season. Pages 33-43 in R. L. Phillips and C. Jonkel, editors. Proceedings of the 1975 Predator Symposium. Montana Forest Conservation Experiment Station, University of Montana, Missoula, Montana, USA.

ERRINGTON, P. L. 1963. Muskrat populations. Iowa State University Press, Ames, Iowa, USA.

GarRison Diversion Unit Commission. 1984. Final Report to the Secretary of the Interior in accordance with Public Law 98-360, Section 207. Washington, D.C., USA.

Gendron, M., AND R. G. Clark. 2002. Survival of gadwall and mallard ducklings in southcentral Saskatchewan. Journal of Wildlife Management 66:170-180.
Gilmer, D. S., L. M. Cowardin, R. L. Duval, L. M. Mechlin, C. W. Shaffer, and V. B. Kuechle. 1981. Procedures for use of aircraft in wildlife biotelemetry studies. U.S. Fish and Wildlife Service Resource Publication 140.

Hall, E. R. 1981. The mammals of North America. John Wiley \& Sons, New York, New York, USA.

Higgins, K. F., L. M. Kirsch, A. T. Klett, AND H. W. MilleR. 1992. Waterfowl production on the Woodworth Station in south-central North Dakota, 1965-1981. U.S. Fish and Wildlife Service Resource Publication 180.

KIEL, W. H., A. S. Hawkins, AND N. G. Perret. 1972. Waterfowl habitat trends in the aspen parkland of Manitoba. Canadian Wildlife Service Report Series 18.

Klett, A. T., H. F. Duebbert, C. A. FaAnes, ANd K. F. HigGINS. 1986. Techniques for studying nest success of ducks in upland habitats in the Prairie Pothole Region. U.S. Fish and Wildlife Service Resource Publication 158.

Koskomies, J., AND L. LAHTI. 1964. Cold-hardiness of the newly hatched young in relation to ecology and distribution in ten species of European ducks. Auk 81:281-307.

Krapu, G. L., D. A. Brandt, And J. A. Beiser. 2001. Factors associated with autumn rearing of duck broods in temperate North America. Wildfowl 52:145-158.

—, P. J. Pietz, D. A. Brandt, and R. R. Cox, JR. 2000. Factors limiting mallard brood survival in prairie pothole landscapes. Journal of Wildlife Management 64:553-561.

- AND K. J. REINECKE. 1992. Foraging ecology and nutrition. Pages 1-29 in B. D. J. Batt, A. D. Afton, M. G. Anderson, C. D. Ankney, D. H. Johnson, J. A. Kadlec, and G. L. Krapu, editors. Ecology and management of breeding waterfowl. University of Minnesota Press, Minneapolis, Minnesota, USA.

Lokemoen, J. T., H. F. Duebbert, ANd D. E. Sharp. 1990. Homing and reproductive habits of mallards, gadwalls, and blue-winged teal. Wildlife Monographs 106.

—, AND D. E. SHARP. 1985. Assessment of nasal marker materials and designs used in dabbling ducks. Wildlife Society Bulletin 13:53-56.

Manly, B. F. 1991. Randomization and Monte Carlo methods in biology. Chapman \& Hall, London, United Kingdom.

MARCSTROM, V. 1966. Mallard ducklings (Anas platyrhynchos L.) during the first days after hatching. Viltrevy 4:343-368.

Mauser, D. M., And R. L. Jarvis. 1991. Attaching radio transmitters to 1-day old ducklings. Journal of Wildlife Management 55:488-491.

MECH, L. D. 1983. Handbook of animal radio-tracking. University of Minnesota Press, Minneapolis, Minnesota, USA.

Murkin, H. R., AND L. C. M. Ross. 2000. Invertebrates in prairie wetlands. Pages 201-247 in Prairie wetland ecology: the contribution of the marsh ecology research program. Iowa State University Press, Ames, Iowa, USA.

National OCEANic and Atmospheric Administration. 1992-1993. Climatological data: North Dakota and Minnesota, monthly summaries. National Climatic Center, Asheville, North Carolina, USA.

OrthmeYeR, D. L., AND I. J. BALL. 1990. Survival of mallard broods on Benton Lake National Wildlife Refuge 
in northcentral Montana. Journal of Wildlife Management 54:62-66.

Pietz, P. J., D. A. Brandt, G. L. Krapu, and D. A. Buhl. 1995. Modified transmitter attachment method for adult ducks. Journal of Field Ornithology 66:408-417. , G. L. Krapu, D. A. Brandt, and R. R. Cox, JR. 2003. Factors influencing gadwall brood and duckling survival in prairie pothole landscapes. Journal of Wildlife Management 66:564-575.

RotelLA, J. J., AND J. T. RATTI. 1990. Use of methoxyflurane to reduce nest abandonment of mallards. Journal of Wildlife Management 54:627-628.

SALYER, J. W. 1962. A bow-net trap for ducks. Journal of Wildlife Management 26:219-221.

Sargeant, A. B., R. J. Greenwood, M. A. Sovada, and T. L. SHAFFER. 1993. Distribution and abundance of predators that affect duck production-Prairie Pothole Region. U.S. Fish and Wildlife Service Resource Publication 194.

, G. A. Swanson, AND H. A. Doty. 1973. Selective predation by mink, Mustela vison, on waterfowl. American Midland Naturalist 89:208-214.

Sauer, J. R., and B. K. Williams. 1989. Generalized chisquare procedures for testing hypotheses about survival or recovery rates. Journal of Wildlife Management 53:137-142.

SOPER, D. J. 1946. Mammals of the northern Great Plains along the international boundary in Canada.
Journal of Mammalogy 27:127-153.

1961. Field data on the mammals of southern Saskatchewan. Canadian Field-Naturalist 75:23-41.

STOudT, J. H. 1971. Ecological factors affecting waterfowl production in the Saskatchewan parklands. U.S. Fish and Wildlife Service Resource Publication 99.

Talent, L. G., R. L. JaRvis, AND G. L. Krapu. 1983. Survival of mallard broods in south-central North Dakota. Condor 85:74-78.

U.S. Bureau of Reclamation. 1974. Final environmental statement, initial stage, Garrison Diversion Unit.

U.S. Department of THE INTERIOR. 1979. Garrison Diversion Unit: final comprehensive supplementary environmental statement. Volume 1. FES 79-7.

Weller, M. W. 1956. A simple field candler for waterfowl eggs. Journal of Wildlife Management 20:111-113.

Winter, T. C., AND D. O. Rosenberry. 1998. Hydrology of prairie pothole wetlands during drought and deluge: a 17-year study of the Cottonwood Lake Wetland Complex in North Dakota in the perspective of longer term measured and proxy hydrological records. Climate Change 40:189-209.

Received 19 December 2002.

Accepted 17 December 2003.

Associate Editor: Sheaffer. 